\title{
MAJOR PERSONALITY TRAITS INFLUENCING ENVIRONMENTAL KNOWLEDGE: A CASE OF URBAN LEARNING ECOLOGIES
}

\author{
Olugbenga Adedayo Ige, Loyiso C. Jita, Thuthukile Jita \\ University of the Free State, South Africa \\ Email: IgeOA@ufs.ac.za, JitaLC@ufs.ac.za, JitaT@ufs.ac.za
}

\begin{abstract}
The grim actualities of modern societies have shifted the attention of human beings from civil wars and beggary to environmental issues such as pollution and climate change. The subtle shifts in environmental balance that are observable from global warming, water scarcity, and poor harvest resulting from erratic rainfall distributions across different countries of the world has led to global campaigns in order to promote positive environment behavioural change. Several change agents have advocated the use of mitigation practices such as using emerging western and indigenous technologies and renewable energies, they have overlooked the major personality traits that will implement the proposed changes. Hence, this research explores the influence of major personality traits on students' environmental knowledge in urban learning spaces. The social cognitive theory was used to untangle the conforming and non-conforming environmental behaviours of students in urban learning spaces. The research adopts a 'field-based' $M O$ to gather data from four hundred and sixty-two students that were randomly selected from thirteen secondary schools in urban centres in Nigeria. Research instruments such as the NEO Five-Factor Inventory and Environmental Knowledge Test were adapted to collect data from the selected students. The quantitative data were subjected to multiple regression analysis. Results showed that there was a significant influence of the major personality factors on students' environmental knowledge $(R=$ 0.297). The research recommends that teachers should include these major personality traits in the environmental education programme of their schools.
\end{abstract}

Keywords: environmental education, environmental knowledge, field-based research, major personality traits, students, urban learning spaces.

\section{Introduction}

Researchers are working assiduously to find scientific solutions to the myriads of environmental problems confronting man in his immediate environment. Most environmental problems that human beings are grappling with at present have connections with the personality characteristics of human beings inhabiting such environments. Personality traits and personal values are integral psychological characteristics that could potentially influence many outcomes (Parks-Leduc, Feldman, \& Bardi, 2014). One of such outcomes in education is students' environmental knowledge. The dawn of the twenty-first century erupted with academic research that investigated the connections between personality traits and numerous outcomes in education and politics, and other related disciplines. For instance, Ha and Lau (2015) expanded on previous research and examined the effect of personality on correct voting which encompasses the level at which personal preference and values determined the voting behaviours of citizens. $\mathrm{Ha}$ and Lau (2015) analysed the common content Cooperative Campaign Analysis Project 
Olugbenga Adedayo IGE, Loyiso C. JITA, Thuthukile JITA. Major personality traits influencing environmental knowledge: A case of urban learning ecologies

\section{PROBLEMS \\ OF EDUCATION \\ IN THE $21^{\text {st }}$ CENTURY Vol. 77 , No. 1, 2019 \\ 40}

sample collected from 2007 to 2008 in relation to the major personality characteristics of the participants. These scholars included in their models of analysis, personalized determinants of correct voting such as political motivation, cognitive capacity, and heuristics availability which were taken from the work of Lau, Anderson and Redlawsk (2008). The study provides evidences that the 'Big Five' personality traits classified as 'major personality traits' in this study exerted a direct influence on correct voting and moderated the effect of party identification which has a long history of determining 'vote choice'. Tidwell and Sias (2005) stated that openness and conscientiousness independently predicted environmentally friendly behaviours, while the effects of these independent variables were conciliated by pro-environmental attitudes.

Scholars who have researched on the link between personality and educational outcomes are: Tidwell and Sias (2005) who investigated how personality traits influenced informationseeking behaviours of one hundred and eighty-seven new employees at a large 4-year university. Brick and Lewis (2014) also sought answers to how core traits can predict ecologically friendly behaviours. Brick and Lewis (2014) used a sample of three hundred and forty-five adults in the United States that completed an online survey on Amazon MTurk. These three hundred and forty-five participants were residents in forty-seven states in the United States. The analyses of the data collected from these participants revealed that openness and conscientiousness independently predicted environmentally friendly behaviours, while the effects of these independent variables were conciliated by pro-environmental attitudes. This research was different from previous studies because it focuses on secondary school students in a developing context. Unlike previous studies by Ha and Lau (2014) that used adult participants, this current research used young secondary school children in urban schools whose parental educational background ranged from standard VI to doctorate degrees. This research described the nexus between personality traits and environmental knowledge of students in urban schools. The researchers drew on the findings to suggest how teachers in urban learning spaces can create learning experiences to raise the personality traits that can improve students' knowledge about their immediate environment.

\section{Major Personality Traits}

The big five personality traits are classified as 'major personality traits' in this research. McCrae and John (1992) describe the five-factor model of personality as a hierarchically assemblage of five basic dimensions of personality traits such as extraversion, agreeableness, conscientiousness, neuroticism and openness to experience. Linden, Dunkel, Figueredo, Garven, Rueden, and Woodley (2018) asserted that the big five dimensions constitute the most meaningful personality factors that are conceptually independent of one another. Linden et al. (2018) pointed out that recent research has shown that the big five factors are not statistically independent but have consistent and relevant intercorrelations which account for a larger shared variance tagged 'the general factor of personality'. Laher (2013) who completed a study on 'understanding the five-factor model and five-factor theory through a South African cultural lens' affirmed the suitability of the major personality traits such as openness to new experience intellect, conscientiousness, extraversion, agreeableness, altruism and neuroticism tagged ' $\mathrm{O}$, C, E, A, N' by Linden et. al. (2018) were employed in this study. Laher (2013) discovered that the five-factor traits evaluated in this study are theoretically and empirically friendlier to other cultural perspectives on personality.

\section{Openness to New Experience or Intellect}

Openness to new experience is one of the traits that are classified as the 'major personality' traits in this study. Vuyk, Krieshok, and Kerr (2016) defined this construct from the perspective 
of Costa and McCrae (1992) that it described individuals who are open to new experiences, enjoy both outer and inner worlds, are curious, and hold creative ideas. This factor becomes relevant in this study because students who will be knowledgeable about the environment should enjoy both their outer and inner immediate environments. With Schilpzand, Herod, and Shalley's (2011) declaration that personality is best described well in terms of the five broad generality traits called the 'big five', it becomes appropriate to assess the influence of openness to new experience on students' environmental knowledge in urban learning spaces.

\section{Conscientiousness}

Another major component of the major personality factors examined in the current study is conscientiousness. Heaven and Ciarrochi (2008) stated that 'conscientiousness' which is a part of the five-factor taxonomy of personality genus is confirmed to have robust links to academic achievement, which is closely related to 'environmental knowledge' assessed in this study. 'Conscientiousness', otherwise called 'dependability' and 'will to achieve' by Heaven, Ciarrochi, Leeson, and Barkus (2012). Heaven et al. (2012) agree with Costa and McCrae's (1998) assertion that highly conscientious people are hardworking, goal oriented, have potentials to follow tasks through to completion, and require little supervision. Other scholars stated that conscientiousness reflects diligence, organization, and achievement orientation (see McCrae \& John, 1992; Zaman, Anis-ul-Haque \& Nawaz, 2014). Watson, Nus and Wu (2017, p.4) extensively review relevant literature and identified twelve conceptual domains in conscientiousness which are: achievement, caution, deliberation, dependability, dutifulness, goal orientation, hard work, dependability, organization, responsibility, risk aversion, and selfdiscipline. These conceptual domains identified by Watson et al. (2017) are of relevance to the environment of students investigated in the current study.

\section{Extraversion}

One of the dimensions of the big five models of personality is extraversion. It is featured in popular personality questionnaires such as Eysenck personality questionnaire and Neo Five-Factor Inventory-3 (Kim \& Nassaji, 2017, p.7). Malhotra, Reus, Zhu, and Roelofsen (2018:372) acknowledge that extraversion is a fundamental personality trait whose construct and meanings have evolved over time. Malhotra et al. (2018) declare that extraversion is the strongest and most consistent personality predictor of effective and transformational leadership. It is possible to state from the findings of Malhotra et al. (2018) that extraversion could have an influence or relationship with students' environmental knowledge in urban learning spaces. Seidman (2018:5) declares that extraversion involves sociability, activity, excitement seeking and creating energy through outside means.

\section{Agreeableness}

Scholars admit that agreeableness is basically concerned with interpersonal relationships with the underlying desire to maintain positive relations with others (Greene \& Robertson, 2017; Grazio \& Eisenberg, 1997). Barrick and Mount (1991) pointed out that traits associated with agreeableness are: being courteous, flexible, trusting, good natured, cooperative, forgiving, soft-hearted and tolerant. Benoliel and Schechter (2017) stated that agreeableness is concerned with the intention to seek the good of the community (see also Liao, Joshi, \& Chuang, 2004). It could be inferred from the assertion of Liao et al. (2004) that agreeable students who are environmentally knowledgeable will cultivate beneficial relationships with their immediate environment. 


\author{
PROBLEMS \\ OF EDUCATION \\ IN THE $21^{\text {st }}$ CENTURY \\ Vol. 77, No. 1, 2019 \\ 42
}

\section{Neuroticism}

Neuroticism is an integral broad high-order trait in the big five model of personality (Laceulle, Ormel, Aggen, Neale, \& Kendler, 2013, p.1780). McCann (2018:157) declared that individuals who are high on the neuroticism dimension have marked behavioural features such as vulnerability, anxiety, angry hostility, self-consciousness, depression and impulsiveness. McCann (2018) further reveals that 'neuroticists' tend to be moody, discontented, insecure, emotional, unstable, envious, guilt-ridden, nervous and tense. Despite scholars' assertion that these general tendencies are the core of the neurotic domain, Benoliel and Schechter (2017) confirmed that highly neurotic individuals seldom engage in social interactions or knowledge sharing which can limit the frequencies of interactions that such students may have with their colleagues, a possibility which can impair knowledge sharing opportunities on environmental conservation issues.

\section{Connections between Personality Traits and Environmental Knowledge}

The campaigns to protect and preserve environmental resources have gained momentum in different nations of the world. This awareness on environmentally friendly behaviours has even spread to different disciplines in humanities, science, social sciences and education. For instance, in Canada, Kennedy, Hyde and Karney (2002) stated that most professional engineering bodies demand practicing engineers' commitment to the environment to the level of acting as environment advocates. The urgency to start assessing the relationship between personality traits and the knowledge of human beings about the environment is predicated by scholars' (Bleys, Defloor, Ootegen, \& Verhofstadt, 2018; Steffen, Richardson, Rockstrom, Cornell, Fetzer, Bennett, \& Sorlion, 2015) assertion that human beings have transgressed key factors such as climate change, transmitted biogeochemical cycles, privation of the integrity of biosphere, climate variability, and changes in land system. It is consequent on these environment alterations that Bleys et al. (2018) advocated that government should devise means of promoting environmentally friendly behaviours.

In Wuertz's (2015) study on personality traits associated with environmental concern; Wuertz (2015) evaluated the correlation between the big five personality traits and proenvironmental attitudes or pro-environmental behaviours. Wuertz (2015) discovered that agreeableness and openness significantly predicted pro-environmental behaviours, while openness was positively correlated with general ecological behaviour and environmental concern. Several researchers have sought explanations on the relationship between the major personality traits (i.e. Big Five) and different social outcomes with interesting findings. Thus, this research seeks to evaluate the connections between major personality traits and students' environmental knowledge. This research seeks answers to these research questions:

1. What is the combined influence of the major personality traits on secondary school students' environmental knowledge?

2. What is the relative influence of the major personality traits on secondary school students' environmental knowledge?

Most attempts at fostering students' knowledge about the environment have focused on complex scientific experiments that do not take cognisance of the behavioural make-up of people residing in an environment. The solutions provided by such scientific experiments to environmental problems are subsequently short-lived because the personality characteristics of people in the immediate environment that are end users are overlooked in its implementation. It is anticipated that the findings of this research would provide information to teachers on the links between students' major personality traits and their knowledge about their immediate environment. 
Olugbenga Adedayo IGE, Loyiso C. JITA, Thuthukile JITA. Major personality traits influencing environmental knowledge: A case of urban learning ecologies

\section{Urban Learning Spaces}

Urban learning spaces are ecologies (schools) in which learning occurs in urban geographical locations (Ige, 2017, p. 311). The definition of learning ecologies by Ige (2017) only focuses on learning spaces in the urban context with a specific focus on schools. Ige (2017) left out other important components of urban learning ecologies such as virtual communities and peer communities that have emerged as features of urban living that enable school children to mutually share ideas with each other.

Barron $(2004$, p. 6) describes a learning ecology as the accessed set contexts that consist of configurations of activities, material resources and relationships found in co-located physical or virtual spaces that provide opportunities for learning. Barron (2004) explained further that the physical contexts connote where students live which are considered crucial sources of learning. In this study, urban ecologies comprise the physical and virtual resources that support students learning experiences. It should be noted that secondary school students are the primary node in the system.

\section{Social Cognitive Theory}

A theory that has received attention from scholars in predicting and explaining social behaviours is the social cognitive theory propounded by Albert Bandura (Lee, Park, Lee, Kim, \& Park, 2018, p. 974). Bandura (2018, p. 30) affirms that the social cognitive theory bestows a paramount role on agentic properties in psychosocial functioning. Bandura (2018) additionally explains that forethought, self-reactiveness and self-reflectiveness are the main properties of the agentic portion of the social cognitive theory. Lee et al. (2018) elaborate that social cognitive theory postulates that human behaviour is determined by the environmental influences. Bandura (1989) admits that, contrary to the general one-sided determinism in explaining human behaviour, social cognitive theory favours a triadic reciprocal determinism in providing the basis for human behaviour, and cognition. Other personal factors and environmental influence are the interacting determinants of the 'triadic reciprocal determinism model'. The social cognitive theory emphasizes the capabilities of human beings to communicate the meanings of behaviour, their ability to forecast the product of a certain behavioural patterns, acquire knowledge by observing other people, to self-regulate behaviour, and to review and scrutinize whether a behaviour will materialize in a specific condition (Amaya \& Petosa, 2011, p. 134).

Bandura (2018) in explaining the main properties of agentic aspects of the social cognitive theory pointed out that forethought involves self-motivation and self-guidance to create action plans, adopt goals and visualize the effect of individual behavioural management using self-sanctions in a self-governing system. Self-reflectiveness on individual's ability to reflect on his/her efficacy to actualize given challenges using metacognitive capabilities. The social cognitive theory is applicable to this research because it could be inferred from the agentic portion of this theory that inadequate consideration of what may happen in the future is the primary causation of Bleys et al's. (2015) observation of human transgression of four of the nine planetary boundaries which has culminated in visible environmental problems linked to human behaviours. The researchers believe that the second and third agentic properties of 'selfreactiveness and 'self-reflectiveness' that strongly account for environmental sustainability are best promoted through students that are knowledgeable about the environment. 
Olugbenga Adedayo IGE, Loyiso C. JITA, Thuthukile JITA. Major personality traits influencing environmental knowledge: A case of urban learning ecologies

\author{
PROBLEMS \\ OF EDUCATION \\ IN THE $21^{\text {st }}$ CENTURY \\ Vol. 77 , No. 1, 2019 \\ 44 Research Methodology
}

\title{
Research Design
}

The 'field-based' MO was adopted by the researchers to collect information on the influence of major personality traits on secondary school students' environmental knowledge. This method was considered appropriate because it enables the researchers to collect data without manipulating any variable of interest in the study (Ige, Amosun \& Ogunleye, 2012, p. 73; Ige \& Orungbemi, 2013; Ige, 2016). The major personality traits examined in this study are limited to extraversion, agreeableness, conscientiousness, neuroticism and openness to experience.

\section{Participant Selection and Sample}

The participants were 243 male and 219 female senior students selected from thirteen secondary schools in urban centres in Ondo State, Nigeria. The thirteen secondary schools were purposefully selected for the study because they were ready to participate in this research. 430 of the selected students were Christians, 30 were Muslims, 2 of the subjects did not indicate their religion on the questionnaire distributed to the participants. 311 subjects indicated their fathers had basic education, 160 subjects indicated their fathers had university degrees and polytechnic diplomas, 56 subjects stated their fathers had postgraduate degrees, 7 indicated their fathers had other types of education, while 28 did not indicate their fathers' educational qualifications. 132 subjects indicated that their mothers had basic education, 115 subjects indicated that their mothers had secondary school education, 75 subjects stated that their mothers had National Teaching Certificates, 19 indicated their mothers are Higher National Diploma holders, 38 stated their mothers had university degrees, while 29 indicated their mothers had postgraduate degrees, 49 did not indicate their mothers' educational qualifications. The 462 students selected from intact classes in the thirteen secondary schools that partook in this research constituted the sample.

\section{Questionnaire and Measures}

The broad personality traits were assessed with the NEO Five-Factor Inventory designed by Costa and McCrae (1991), while the Environmental knowledge Test developed by Ajiboye and Ajitoni (2008) was used to assess the selected student's environmental knowledge. The NEO Personality Inventory is a questionnaire measure of a comprehensive model of general personality traits (Costa \& McCrae, 2012). The version of NEO Five-Factor Inventory used in this study consisted of 44-item designed on a 5-point Likert scale of disagree strongly to agree strongly by John and Srivastava (1999). The architects of the NEO Five-Factor Inventory declared that the instrument has been validated extensively (see Costa \& McCrae, 1992; 2012). The instrument comprises neuroticism, extraversion, and openness to experience, agreeableness and conscientiousness, which were taken as major personality traits in this research. Some of the items on 44-item NEO Five Factor Inventory were Neuroticism: I see myself as someone who remains calm in tense situations, Extraversion: I see myself as someone who is outgoing and sociable.

Openness Experience: I see myself as someone who makes plans and follows through with them. Agreeableness: I see myself as someone who likes to cooperate with others. Conscientiousness: I see myself as someone who makes plans and follows through with them.

The reliability coefficient of the NEO Five-Factor Inventory using a split-half method was .77 (Aremu, 2009). 
The 'Environmental Knowledge Test' comprises two sections. Section I elicited response on age, sex, religion, parents' educational background and name of school. Section II evaluated the selected students' knowledge of essential environmental concept such as environment, erosion, deforestation and pollution. The reliability coefficient of the 30-item multiple choice test by the developers using Kuder-Richardson 21 was .92 .

\section{Ethical Conditions}

Permission was sought from the management of the thirteen secondary schools selected for the study. The Principal/Vice Principal of the selected schools visited each intact class selected in the thirteen secondary schools and explained the mission of the researchers to the students. The researchers explained the purpose of the study to the selected students in each intact class and assured them they were free to disengage at any point of their response to the questionnaire without fear of victimization. Only students in each intact class that agreed to participate in the study were handed the questionnaire.

\section{Data Analysis}

The data was subjected to multiple repression analysis to determine the effect of major personality traits on the selected student's environmental knowledge. The independent variables were regressed on the environmental knowledge of the selected students in urban learning ecologies.

\section{Research Results}

Table 1 shows that there is a combined influence of major personality factors such as neuroticism, extraversion, openness to experience, agreeableness and conscientiousness on students' environmental knowledge $(R=0.297)$. The predictors had an adjusted $R^{2}$ of .078 which means neuroticism, extraversion, and openness to experience, agreeableness and conscientiousness accounted for $7.8 \%$ contribution of the total variance in students' environmental knowledge. The analysis of the combined influence generated $F$ of 8.795 at .01 level of significance.

Table 1. The combined influence of major personality traits on students' environmental knowledge.

\begin{tabular}{lccccc}
\hline Model & Sum of Squares & $\boldsymbol{d} \boldsymbol{f}$ & Mean Square & $\boldsymbol{F}$ & $\boldsymbol{p}$ \\
\hline Regression & 705.755 & 5 & 141.151 & 8.795 & $.001^{\mathrm{a}}$ \\
\hline Residual & 7318.594 & 456 & 16.050 & \\
\hline Total & 8024.348 & 461 & & \\
\hline
\end{tabular}

$R=.297, R$ Square $=.088$, Adjusted $R$ Square $=.078$, Std. Error of the Estimate $=4.00619$

a. Predictors: (Constant), conscientiousness, openness, neuroticism, agreeableness, extraversion

b. Dependent Variable: environmental knowledge

Notes. ${ }^{*} p<.01$ 
Olugbenga Adedayo IGE, Loyiso C. JITA, Thuthukile JITA. Major personality traits influencing environmental knowledge: A case of urban learning ecologies

OF EDUCAT

IN THE $21^{\text {st }}$ CENTURY Vol. 77 , No. 1, 2019

Table 2 highlights the relative contribution of the independent variables to the environmental knowledge of the selected students. The standardized Bs and T-test of the predictors are presented:

Consciousness significantly positively influence students' environmental knowledge ( $\beta$ $=0.31, \mathrm{t}-5.33, p>.01)$. The significant influence of conscientiousness on what the students know about the environment in this study implies that environmentally knowledgeable students are highly conscientious students that are hardworking, goal oriented, require little supervision and have potentials to follow environmental sustainability task through to completion.

Openness to new experience or intellect have no significant positive influence on students' environmental knowledge ( $\beta=0.14, t=2.38, p>.01)$ neuroticism had no significant influence on students' environmental knowledge $(\beta=-0.14, t=-2.37, p<.01)$. Agreeableness had no significant influence on students' environmental knowledge $(\beta=-0.11, t=-1.93, p<.01)$. Extraversion had no significant influence on students' environmental knowledge $(\beta=-0.11, t=$ $-2.07, p<.01)$.

Table 2. The relative influence of major personality traits on students' environmental knowledge.

\begin{tabular}{|c|c|c|c|c|c|}
\hline \multirow[t]{2}{*}{ Model } & \multicolumn{2}{|c|}{$\begin{array}{l}\text { Unstandardized } \\
\text { Coefficients }\end{array}$} & \multicolumn{2}{|c|}{$\begin{array}{l}\text { Standardized } \\
\text { Coefficients }\end{array}$} & \multirow[b]{2}{*}{$p$} \\
\hline & B & Std. Error & Beta & $t$ & \\
\hline (Constant) & 8.390 & 1.338 & & 6.271 & .001 \\
\hline conscientiousness & .239 & .045 & .308 & 5.333 & .001 \\
\hline openness & .091 & .038 & .144 & 2.376 & .018 \\
\hline neuroticism & -.123 & .052 & -.137 & -2.371 & .018 \\
\hline agreeableness & -.097 & .050 & -.113 & -1.928 & .055 \\
\hline extraversion & -.106 & .051 & -.112 & -2.072 & .039 \\
\hline
\end{tabular}

a. Dependent Variable: environmental knowledge

Notes. ${ }^{*} p<.01$

\section{Discussion}

The novelty in the current research is that it is one of the pioneering efforts in evaluating the relationship between personality traits and students' environmental knowledge. The answer to the first research question shows that consciousness, openness to new experience, neuroticism, agreeableness and extraversion have an established influence of the environmental knowledge on the selected contribution of the total variance in students' environmental knowledge. This signals that other variables that are not investigated in this research accounted for 92.2 percent of factors that are capable of influencing students' environmental knowledge. The second research question probes the categorical contribution of the five major personality traits on what the selected students know about their environment. The results show that only conscientiousness significantly positive contributed to student's environmental knowledge. This finding confirms Tidwell and Sias's (2005) discovery that openness and conscientiousness independently predicted environmentally friendly behaviours, notwithstanding the conciliatory effects of pro-environmental attitudes.

It should be noted that this judgment was made at .01 level of significance consequent on the researchers' quest to establish relationship between students' major personality traits and what they know about the environment. The environmental hazards that sprang up in the twentyfirst century demand that students must be 99 percent knowledgeable about human activities that 
could alter environmental balance. It was noted that predictors such as openness to experience, neuroticism and extraversion had significant positive influence on students' environmental knowledge at 0.05 level of significance but were discountenanced in this study. The researchers discountenanced these predictors that were significant at .05 level because it would do more harm than good to the environment if a student with personality traits affirming, he/she has a 95 percent knowledge about the environment is taken as environmentally knowledgeable with the current spate of environmental problems emanating from human activities. The researchers are wary of the harm the 95 percent confidence interval will do to the students' immediate environment due to this environmental knowledge deficit. It should be noted that inference drawn from these results are not currently supported by empirical studies, but the elemental fact that the current research has established is that there is a relationship between what a student knows about the environment and his/her major personality traits.

The current debates on environmental sustainability warrant that educational researchers beam their searchlights on the use of 0.05 level of significance as a benchmark for taking judgments on research focusing on the environment consequent scholars cries that humans have transgressed climate change, loss of biosphere integrity, land-system changes and permutated biogeochemical cycles (Steffen et al., 2015; Bleys et al., 2018), which are critical of the nine boundaries of the planet.

\section{Conclusion and Implications for Environmental Education}

The outcomes of this research have implications from teaching environmental education and educational psychology in general. The findings of this study make a strong case for teachers' use of constructive teaching strategies such as inquiry teaching strategy, predictobserve-explain instrumental strategy and action learning strategy to foster the students' conscientiousness in environmental education lessons. This research has shown that the inculcation of the 'conscientiousness' personality trait in students seems to be the key that can unlock students' environmental knowledge. It should be noted that the findings of this study are limited to four hundred and sixty-two students selected from thirteen secondary schools in a developing country. Researchers should be cautious in generalizing the findings of this study to secondary school students in other developing nations. Despite this limitation, this study has contributed to knowledge by unveiling the links between major personality traits and students' environmental knowledge. It is anticipated that the limitations in this study will be surmounted by persistent research in future educational projects.

\section{Acknowledgements}

The authors sincerely appreciate the efforts of Sodeeq Faremi who typed this manuscript at no cost, and Oluwaseun Amusa (Nee Akinbola) who performed the language editing tasks at no cost.

\section{References}

Adu, E. O., Ige, O. A., \& Adu, K. O. (2017). Internet self-efficacy, Computer usage and competency variables influencing university students' Internet use in Southern Nigeria. Retrieved from http:// www.hkaect.org/hkaect-aect-2017/download/paper/P10_4.pdf.

Aremu, A. O. (2009). Measured influence of big-five factor and gender as correlates of academic selfefficacy of educationally distressed adolescents in Ibadan, Nigeria. The African Symposium: An Online Journal of African Educational Research Network, 9 (2), 21-28.

Ajiboye, J. O., \& Ajitoni, S. O. (2008). Effects of full and quasi-participatory learning strategies on Nigeria senior secondary students' environmental knowledge: Implications for classroom practice. International Journal of Environmental \& Science Education, 3 (2), 58-66. 
Olugbenga Adedayo IGE, Loyiso C. JITA, Thuthukile JITA. Major personality traits influencing environmental knowledge: A case of urban learning ecologies

\section{PROBLEMS \\ OF EDUCATION \\ IN THE $21^{\text {st }}$ CENTURY Vol. 77 , No. 1, 2019}

48

Amaya, M., \& Petosa, R.L. (2011). An evaluation of a worksite exercise intervention using the social cognitive theory: A pilot study. Health Education Journal, 71 (2), 133-143.

Barron, B. (2004). Learning ecologies for technological fluency: Gender and experience differences. Journal of Educational Computing Research, 31 (1), 1-36.

Bandura, A. (2018). Toward a psychology of human agency: Pathways and reflections. Perspectives on Psychological Science, 13 (2), 130-136.

Bandura, A. (1989). Social cognitive theory. In R. Vasta (Ed.), Annals of child development. Vol. 6. Six theories of child development (pp. 1-60). Greenwich, CT: JAI Press.

Barrick, M. R., \& Mount, M. K. (1991). The Big Five personality dimensions and job performance: A meta-analysis. Personnel Psychology, 44 (1), 1-26.

Benoliel, P., \& Schechter, C. (2017). Is it personal? Teacher's personality and the principal's role in professional learning communities. Improving Schools, 20 (3), 222-235.

Bleys, B., Defloor, B., Ootegem, L. V., Verhofstadt, E. (2018). The environment impact of individual Behavior: Self-assessment versus the ecological footprint. Environment and Behavior 50 (2), 187212.

Brick, C., \& Lewis, G. J. (2014). Unearthing the 'green' personality: Core traits predict environmentally friendly behavior. Environment and Behavior, 48 (5), 635-638.

Ciarrochi, J. V., \& Heaven, P. C. L. (2007). Longitudinal examination of the impact of Eysenck's psychoticism dimension on emotional well-being in teenagers. Personality and Individual Differences, 42, 597-608.

Costa, P., \& McCrae, R. R. (2012). The Five-Factor Model and the NEO Inventories. In Oxford Handbook of Personality Assessment Oxford University Press. https://doi.org/10.1093/ oxfordhb/9780195366877.013.0016

Digman, J. M. (1997). Higher-order factors of the Big Five. Journal of Personality and Social Psychology, 73 (6), 1246-1256.

Greene, S., \& Robertson, G. (2017). Agreeable authoritarians: Personality and politics in contemporary Russia. Comparative Political Studies, 50 (13), 1802-1834.

Graziano, W. G., \& Eisenberg, N. (1997). Agreeableness: A dimension of personality. In R. Hogan, J. A. Johnson, \& S. R. Briggs (Eds.), Handbook of personality psychology (pp. 795-824). San Diego, CA, US: Academic Press. http://dx.doi.org/10.1016/B978-012134645-4/50031-7

Ha, S. E., \& Lau, R. R. (2015). Personality traits and correct voting. American Politics Research, 43 (6), 975-998.

Heaven, P. C. L., Ciarrochi, J., Leeson, P., \& Barkus, E. (2012). Agreeableness, conscientiousness, and psychoticism: Distinctive influences of three personality dimensions in adolescence. British Journal of Psychology, 104 (4), 481-494.

Ige, O. A. (2016). Reflective thinking and multicultural factors influencing secondary school students' achievement in civic education in southwest, Nigeria. American Journal of Academic Research, 1 (1), A38-A47.

Ige, O. A. (2017). Rethinking students' dispositions towards civic duties in urban learning ecologies. International Journal of Instruction, 10 (4), 307-324.

Ige, O. A., Amosun, P. A., \& Ogunleye, K. A. (2012). The attitude of teachers to national economic empowerment and development strategy in selected secondary schools in Oyo State: Implications for nation building through civics education. Nigerian Journal of Social Studies, XV (3), 69-79.

Ige, O. A., \& Orungbemi, O. O. (2013). Measured effect of gender and computer literacy on students' academic achievement in social studies and civic education in selected secondary schools in Ondo State. International Journal of Research and Development, 1 (2), 104-111.

John, O. P., \& Srivastava, S. (1999). The Big-Five trait taxonomy: History, measurement, and theoretical perspectives. In L. A. Pervin \& O. P. John (Eds.), Handbook of personality: Theory and research (Vol. 2, pp. 102-138). New York: Guilford Press.

Kennedy, C., Hyde, R., Karney, B. (2002). Development of environmental knowledge and attitudes in engineering students. Bulletin of Science, Technology \& Society, 22 (6), 460-473.

Kim, J., \& Nassaji, H. (2017). Incidental focus on form and the role of learner extraversion. Language Teaching Research, 22 (6), 698-718.

Laceulle, O. M., Ormel, J., Aggen, S. H., Neale, M. C., \& Kendler, K. S. (2013). Genetic and environmental influences on the longitudinal structure of neuroticism: A trait-state approach. Psychological Science, 24 (9), 1780-1790. 
Olugbenga Adedayo IGE, Loyiso C. JITA, Thuthukile JITA. Major personality traits influencing environmental knowledge: A case of urban learning ecologies

Laher, S. (2013). Understanding the five-factor theory through a South African cultural lens. South African Journal of Psychology, 43 (2), 208-221.

Lau, R. R., Andersen, D. J., \& Redlawsk, D. P. (2008). An exploration of correct voting in recent U.S. Presidential Elections. American Journal of Political Science, 52, 395-411.

Lee, C. G., Park, S., Lee, S. H., Park, J. (2018). Social cognitive theory and physical activity among Korean male high-school students. American Journal of Men's Health, 12 (4), 973-980.

Liao, H., Chuang, A., \& Joshi, A. (2008). Perceived deep-level dissimilarity: Personality antecedents and impact on overall job attitude, helping, work withdrawal, and turnover. Organizational Behavior and Human Decision Processes, 106 (2008), 106-124.

Linden, D. V. D., Dunkel, C. S., Figueredo, A. J., Gurven, M., Rueden, C. V., \& Woodley of Menie, M. A. (2018). How universal is the general factor of personality? An analysis of the big five in forager farmers of the Bolivian Amazon. Journal of Cross-Cultural Psychology, 49 (7), 1081-1097.

Malhotra, S., Reus, T. H., Zhu, P., \& Roelofsen, E. M. (2018). The acquisitive nature of extraverted CEOs. Administrative Science Quarterly, 63 (2), 370-408.

McCann, H. (2018). U.S. State resident Big Five personality and work satisfaction: The importance of neuroticism. Cross-Cultural Research, 52 (2), 155-191.

McCrae, R. R., \& John, O. P. (1992). An introduction to the five-factor model and its applications. Journal of Psychology, 60 (2), 175-215.

McCrae, R. R., Costa Jr., \& Paul, T. (1992). Reviews NEO personality inventory and NEO five-factor inventory professional manual. Odessa, FL: Psychological Assessment Resources.

McCrae, R. R., \& Costa Jr., P. T. (1998). Six approaches to the explication of facet-level traits: Examples from conscientiousness. European Journal of Personality, 12, 117-134.

Parks-Leduc, L., Feldman, G., \& Bardi, A. (2014). Personality traits and personal values: A meta-analysis. Personality and Social Psychology Review, 19 (1), 3-29.

Seidman, G. (2018). The Big 5 and relationship maintenance on Facebook. Journal of Social and Personal Relationships, https://doi.org/10.1177/0265407518772089.

Steffen, W., Richardson, K., Rockström, J., Cornell, S. E., Fetzer, I. Bennett, E. M., Biggs, R., Carpenter, S. R., De Vries, W., De Wit, C. A., Folke, C., Gerten, D., Heinke, J., Mace, G. M., Persson, L. M., Ramanathan, V., Reyers, B., Sörlin, S. (2015). Planetary boundaries: Guiding human development on a changing planet. Science, 347 (6223), 1259855-1 -1259855-10.

Schilpzand, M. C., Herold, D. M., \& Shalley, C. E. (2011). Members'openness to experience and teams' creative performance. Small Group Research, 42 (1), 55-76.

Tidwell, M., \& Sias, P. (2005). Personality and information seeking: Understanding how traits influence information-seeking behaviours. Journal of Business Communication, 42 (1), 51-77.

Vuyk, A. M., Krieshok, T. S., \& Kerr, B. A. (2016). Openness to experience rather than over excitabilities: Call it like it is. Gifted Child Quarterly, 60 (3), 192-211.

Watson, D., Nus, E., \& Wu, K. D. (2017). Development and validation of the faceted inventory of the five-factor model (FI-FFM). Assessment, 26 (1), 17-44.

Wuertz, T. R. (2015). Personality traits associated with environmental concern. An unpublished PhD thesis submitted to Walden University, United States. Retrieved from https://scholarworks. waldenu.edu/cgi/viewcontent.cgi?referer $=\&$ httpsredir= $=1$ a article $=1307 \&$ context=dissertations.

Zaman, S., Anis-ul-Haques, M., \& Nawaz, S. (2014). Work-family interface and its relationship with job performance: The moderating role of conscientiousness and agreeableness. South African Journal of Psychology, 44 (4), 528-5 
Olugbenga Adedayo IGE, Loyiso C. JITA, Thuthukile JITA. Major personality traits influencing environmental knowledge: A case of urban learning ecologies

PROBLEMS

OF EDUCATION

IN THE $21^{\text {st }}$ CENTURY

Vol. 77, No. 1, 2019

\section{BIG FIVE INVENTORY (BFI)}

\section{Reference}

John, O. P., \& Srivastava, S. (1999). The Big-Five trait taxonomy: History measurement. and theoretical perspectives. In L. A. Pervin \& O. P. John (Eds.), Handbook of personality: Theory and research (Vol. 2, pp. 102-138). New York: Guilford Press.

\section{Description of Measure:}

44-item inventory that measures an individual on the Big Five Factors (dimensions) of personality (Goldberg, 1993). Each of the factors is then further divided into personality facets.

The Big Five Factors are (chart recreated from John \& Srivastava, 1999):

\begin{tabular}{|l|l|}
\hline Big Five Dimensions & Facet (and correlated trait adjective) \\
\hline Extraversion vs. introversion & Gregariousness (sociable) \\
& Assertiveness (forceful) \\
& Activity (energetic) \\
& Excitement-seeking (adventurous) \\
& Positive emotions (enthusiastic) \\
Warmth (outgoing) \\
\hline Agreeableness vs. antagonism & Trust (forgiving) \\
& Straightforwardness (not demanding) \\
& Altruism (warm) \\
& Compliance (not stubborn) \\
& Modesty (not show-off) \\
& Tender-mindedness (sympathetic) \\
\hline Conscientiousness vs. lack of direction & Competence (efficient) \\
& Order (organized) \\
& Dutifulness (not careless) \\
& Achievement striving (thorough) \\
& Self-discipline (not lazy) \\
& Deliberation (not impulsive) \\
\hline Neuroticism vs. emotional stability & Anxiety (tense) \\
& Angry hostility (irritable) \\
& Depression (not contented) \\
& Self-consciousness (shy) \\
& Impulsiveness (moody) \\
& Vulnerability (not self-confident) \\
\hline Openness vs. closedness to experience & Ideas (curious) \\
& Fantasy (imaginative) \\
& Aesthetics (artistic) \\
& Actions (wide interests) \\
& Feelings (excitable) \\
& Values (unconventional) \\
\hline & \\
\hline
\end{tabular}

For more information about the Big Five, visit this website: http://www.uoregon.edu/ sanjay/bigfive. html\#where 


\section{Abstracts of Selected Related Articles:}

Bouchard, T. J. \& McGue, M. (2003). Genetic and environmental influences on human psychological differences. Journal of Neurobiology, 54, 4-45.

Psychological researchers typically distinguish five major domains of individual differences in human behavior: cognitive abilities, personality, social attitudes, psychological interests, and psychopathology (Lubinski, 2000). In this article we: discuss a number of methodological errors commonly found in research on human individual differences; introduce a broad framework for interpreting findings from contemporary behavioral genetic studies; briefly outline the basic quantitative methods used in human behavioral genetic research; review the major criticisms of behavior genetic designs, with particular emphasis on the twin and adoption methods; describe the major or dominant theoretical scheme in each domain; and review behavioral genetic findings in all five domains. We conclude that there is now strong evidence that virtually all individual psychological differences, when reliably measured, are moderately to substantially heritable.

Tkach, C., \& Lyubomirsky, S. (2006). How do people pursue happiness?: Relating personality, happiness-increasing strategies, and well-being. Journal of Happiness Studies, 7, 183-225.

Five hundred ethnically diverse undergraduates reported their happiness strategies - that is, activities undertaken to maintain or increase happiness. Factor analysis extracted eight general strategies: Affiliation, Partying, Mental Control, Goal Pursuit, Passive Leisure, Active Leisure, Religion, and Direct Attempts at happiness. According to multiple regression analyses, these strategies accounted for $52 \%$ of the variance in self-reported happiness and $16 \%$ over and above the variance accounted for by the Big Five personality traits. The strongest unique predictors of current happiness were Mental Control (inversely related), Direct Attempts, Affiliation, Religion, Partying, and Active Leisure. Gender differences suggest that men prefer to engage in Active Leisure and Mental Control, whereas women favor Affiliation, Goal Pursuit, Passive Leisure, and Religion. Relative to Asian and Chicano(a) students, White students preferred using high arousal strategies. Finally, mediation analyses revealed that many associations between individuals personality and happiness levels are to some extent mediated by the strategies they use to increase their happiness - particularly, by Affiliation, Mental Control, and Direct Attempts.

Shiota, M.N., Keltner, D., \& John, O. P. (2006). Positive emotion dispositions differentially associated with Big Five personality and attachment style. The Journal of Positive Psychology, 1, 61-71.

Although theorists have proposed the existence of multiple distinct varieties of positive emotion, dispositional positive affect is typically treated as a unidimensional variable in personality research. We present data elaborating conceptual and empirical differences among seven positive emotion dispositions in their relationships with two core personality constructs, the "Big Five" and adult attachment style. We found that the positive emotion dispositions were differentially associated with self- and peer-rated Extraversion, Conscientiousness, Agreeableness, Openness to Experience, and Neuroticism. We also found that different adult attachment styles were associated with different kinds of emotional rewards. Findings support the theoretical utility of differentiating among several dispositional positive emotion constructs in personality research. 
Olugbenga Adedayo IGE, Loyiso C. JITA, Thuthukile JITA. Major personality traits influencing environmental knowledge: A case of urban learning ecologies

PROBLEMS

OF EDUCATION

IN THE $21^{\text {st }}$ CENTURY

Vol. 77, No. 1, 2019

52

Scale:

\section{The Big Five Inventory (BFI)}

Here are a number of characteristics that may or may not apply to you. For example, do you agree that you are someone who likes to spend time with others? Please write a number next to each statement to indicate the extent to which you agree or disagree with that statement.

$\begin{array}{ccccc}\begin{array}{c}\text { Disagree } \\ \text { strongly }\end{array} & \begin{array}{c}\text { Disagree } \\ \text { a little }\end{array} & \begin{array}{c}\text { Neither agree } \\ \text { nor disagree }\end{array} & \begin{array}{c}\text { Agree } \\ \text { a little }\end{array} & \begin{array}{c}\text { Agree } \\ \text { Strongly }\end{array} \\ 1 & 2 & 3 & 4 & 5\end{array}$

I see Myself as Someone Who...

1. Is talkative

2. Tends to find fault with others

3. Does a thorough job

4. Is depressed, blue

5. Is original, comes up with new ideas

6. Is reserved

7. Is helpful and unselfish with others

8. Can be somewhat careless

9. Is relaxed, handles stress well

10. Is curious about many different things

11. Is full of energy

12. Starts quarrels with others

13. Is a reliable worker

14. Can be tense

15. Is ingenious, a deep thinker

16. Generates a lot of enthusiasm

17. Has a forgiving nature

18. Tends to be disorganized

19. Worries a lot
23. Tends to be lazy

24. Is emotionally stable, not easily upset

25. Is inventive

26. Has an assertive personality

27. Can be cold and aloof

28. Perseveres until the task is finished

29. Can be moody

30. Values artistic, aesthetic experiences

31. Is sometimes shy, inhibited

32. Is considerate and kind to almost everyone

33. Does things efficiently

34. Remains calm in tense situations

35. Prefers work that is routine

36. Is outgoing, sociable

37. Is sometimes rude to others

38. Makes plans and follows through with them

39. Gets nervous easily

40. Likes to reflect, play with ideas

41. Has few artistic interests 
Olugbenga Adedayo IGE, Loyiso C. JITA, Thuthukile JITA. Major personality traits influencing environmental knowledge: A case of urban learning ecologies

PROBLEMS

OF EDUCATION

IN THE $21^{\text {st }}$ CENTURY

Vol. 77, No. 1, 2019

20. Has an active imagination

21. Tends to be quiet

22. Is generally trusting
42. Likes to cooperate with others

43. Is easily distracted

44. Is sophisticated in art, music, or literature

\section{Scoring:}

BFI scale scoring (" $\mathrm{R}$ " denotes reverse-scored items):

Extraversion: 1, 6R, 11, 16, 21R, 26, 31R, 36

Agreeableness: 2R, 7, 12R, 17, 22, 27R, 32, 37R, 42

Conscientiousness: $3,8 \mathrm{R}, 13,18 \mathrm{R}, 23 \mathrm{R}, 28,33,38,43 \mathrm{R}$

Neuroticism: 4, 9R, 14, 19, 24R, 29, 34R, 39

Openness: 5, 10, 15, 20, 25, 30, 35R, 40, 41R, 44 
Olugbenga Adedayo IGE, Loyiso C. JITA, Thuthukile JITA. Major personality traits influencing environmental knowledge: A case of urban learning ecologies

OF EDUCATION

IN THE $21^{\text {st }}$ CENTURY

Vol. 77 , No. 1, 2019
Received: October 30, 2018
Accepted: January 12, 2019

\section{Olugbenga Adedayo Ige}

(Corresponding author)

Loyiso C. Jita

Thuthukile Jita
Postdoctoral Research Fellow, SANRAL Chair in Science and Mathematics Education, Faculty of Education, University of the Free State, P.O Box 339, Bloemfontein 9300, Republic of South Africa. Email: IgeOA@ufs.ac.za

Dean and SANRAL Chair in Science and Mathematics Education, Faculty of Education, University of the Free State, P.O Box 339, Bloemfontein 9300, Republic of South Africa.

E-mail: JitaLC@ufs.ac.za

Lecturer, Faculty of Education, University of the Free State, P.O Box 339, Bloemfontein 9300, Republic of South Africa.

E-mail: JitaT@ufs.ac.za 